Article

\title{
EU Legislation on Forest Plant Health: An Overview with a Focus on Fusarium circinatum
}

\author{
Anna Maria Vettraino ${ }^{1, *(\mathbb{C})}$, Roel Potting ${ }^{2}\left(\mathbb{D}\right.$ and Rosa Raposo ${ }^{3}$ \\ 1 Department for Innovation in Biological, Agro-food and Forest Systems (DIBAF), University of Tuscia, \\ via S. Camillo de Lellis, snc, 01100 Viterbo, Italy \\ 2 Office for Risk Assessment and Research, Netherlands Food and Consumer Product Safety Authority, \\ P.O. Box 43006 Utrecht, The Netherlands; r.p.j.potting@nvwa.nl \\ 3 National Institute for Agricultural and Food Research and Technology and agrifood-Forest Research \\ Centre (INIA-CIFOR), Ctra. Coruna km. 7.5, 28040 Madrid, Spain; raposo@inia.es \\ * Correspondence: vettrain@unitus.it
}

Received: 31 July 2018; Accepted: 12 September 2018; Published: 14 September 2018

\begin{abstract}
The increase in arrivals of new forest pests highlights the need for effective phytosanitary legislation and measures. This paper introduces legislation targeted at prevention and management of potential introductions of forest pests and pathogens. An overview is given on plant health regulations on global and regional level with detailed information on the situation in the European Union (EU). The current and new European legislation is discussed, and a particular focus is given on eradication and contingency plans for Fusarium circinatum. We identified key aspects relevant for the improvement of the efficacy of measures aimed to prevent alien pests.
\end{abstract}

Keywords: EU legislation; plant health; invasive alien species; Fusarium circinatum; pitch canker; contingency plan; pest risk analysis (PRA); international standards for phytosanitary measures (ISPMs); EPPO standards

\section{Introduction}

The health of the earth's forests and urban and sub-urban green spaces is increasingly challenged by the outcomes of the recurrent introduction of invasive alien species (IAS), defined by the Convention on Biological Diversity (CBD-1993) as "species whose introduction and/or spread outside their natural past or present distribution threatens biodiversity" [1]. In the last century, the numbers of IAS in Europe greatly increased [2-4]. This proliferation is due to several reasons, some of which are within the control of regulatory authorities and some of which are not. However, the role of the plant trade as a major invasion pathway for IAS was recognised in several studies [5-7]. Alien pests arrive also by accident, in packaging material, in ship ballast tanks, shipping containers or with travellers. Interestingly, their introduction is sometimes a consequence of movement of military personnel during wars and conflicts. That was the case with Heterobasidion irregulare, introduced by the 85th division of the US Fifth Army in June 1944, in Central Italy [8], and Diatrobica virgifera virgifera, first introduced in Europe in 1990 by military air transport from North America [9].

Forest IAS have a huge and potentially devastating impact on native plants due to the absence of their specific natural predators, competitors, and pathogens, and the lack of a co-evolutionary process with the hosts, that would limit their invasion [10,11].

Protecting forests from IAS is essential, but it remains a major challenge because effective management strategies are difficult to develop. Therefore, actions, implemented mainly through regulatory measures, to prevent introduction and spread of invasive species, are of special relevance.

One of the major forest destructive pests is the pine wood nematode (PWN-Bursaphelenchus xylophilus), which was introduced to Portugal, in the Setùbal Peninsula, during the late 1990s and 
early 2000s [12]. Its introduction in new non-native areas has resulted in serious ecological and economic damage to pine forests. Despite the emergency measures implemented by the Portuguese authorities and the European Union to prevent its further spread, the nematode established in other regions of Portugal [13-16]. Moreover, Finland, Spain, and Sweden received the nematode in wood materials imported from Portugal [17]. If no regular control measures are applied against the PWN, the economic impact of lost forestry stock is estimated to reach $€ 22$ billion for Europe by 2030 [18]. The probability of successful eradication of PWN in a new non-native area is reliably low, and could require impractical emergency measures [19]. Moreover, eradication treatments, when applicable, are very expensive. Eradication efforts against sudden oak death (SOD), caused by Phytophthora ramorum, introduced via live plants $[20,21]$ on approximately 560 ha of forest land in Oregon, resulted in a cost of 2.6 million US\$ for the United States [22]. The eradication programme for Anoplophora glabripennis was 373 million US\$ for the United States. In Europe, the cost ranged from $€ 48,000$ to $€ 464,000$, according to the number of outbreaks and the type and schedule of treatments applied [23]. The success of the eradication programme can also be compromised by the ecology of the pathogen. The presence of Fusarium circinatum as a symptomless endophyte on herbaceous plants could affect the occurrence of the disease in pine nurseries and forest and, consequently, the management costs [24,25]. On the other hand, eradication programmes allow for a significant reduction of the damage and the protection of ecosystem services provided by trees.

Policy and management should also take into account the interactive effects of climate change and IAS on forest health. Pests and pathogens have the capacity to respond faster to environmental changes compared to their forest hosts. This may influence changes in spread, establishment, and impact of the diseases they cause [26-28].

The awareness of the risk of invasive species is reflected in a suite of international, European, and national policy legislation developed at different scales to prevent the introduction and spread of IAS within and among countries, regions, or areas. Over the past 120 years, the existing international regulation and management of non-native plant pests have continuously evolved [29]. Most countries base their phytosanitary regulations on the International Plant Protection Convention (IPPC) and the World Trade Organisation's Agreement on Sanitary and Phytosanitary Measures [30]. Nevertheless, approaches with different phytosanitary regulations are applied for managing the risk of introducing invasive alien species through international plant trade [31]. This paper aims to provide an overview of the current main European information sources on plant health for forestry in general with a focus on Fusarium circinatum Nirenberg, O'Donnell.

\section{Current European Plant Health Legislation}

The IPPC is the framework that determines the phytosanitary barriers to international trade. A total of 183 countries are currently under contract with the IPPC [32], including all member states of the EU. The IPPC provides International Standards for Phytosanitary Measures (ISPMs), that can be used by member states to achieve international agreement of phytosanitary measures. Examples of ISPMs relevant to forest pests and pathogens include ISPM 15 (Regulation of wood packaging material in international trade), ISPM 38 (International movement of seeds), and ISPM 39 (International movement of wood) [33-35]. National Plant Protection Organizations (NPPOs) follow the IPPC (Figure 1) and implement ISPMs in legislative and administrative procedures, to prevent plant pests from entering and spreading within their territories [36]. This is often referred to as plant health or phytosanitary legislation. In international plant trade, NPPOs interact with exporting and importing countries by agreeing on phytosanitary requirements. In this respect, the NPPO of the exporting country guarantees that exported plant material fulfils the phytosanitary requirements of the importing country. NPPOs often collaborate and harmonise phytosanitary measures at a regional level throughout the Regional Plant Protection Organizations (RPPOs). Regional standards for phytosanitary measures, developed in a RPPO, can be adopted by the IPPC in the form of ISPMs, which have a global reach. 
For example, ISPM 36 [37] was initiated as the North American Plant Protection Organization's Regional Standard for Phytosanitary Measures 24 [38].

The European and Mediterranean Plant Protection Organization [39] (EPPO) is the RPPO for Europe. Founded in 1951, EPPO now includes 51 member countries, with nearly every country in the European and Mediterranean region, and aims to:

- $\quad$ protect plant health in agriculture, forestry, and the uncultivated environment;

- develop an international strategy against the introduction and spread of pests (including invasive alien plants) that damage cultivated and wild plants, in agricultural and natural ecosystems and protect biodiversity;

- encourage harmonization of phytosanitary regulations and all other areas of official plant protection action;

- $\quad$ promote the use of modern, safe, and effective pest control methods;

- provide a documentation and information service on plant protection.

One of the missions of EPPO is to help its member countries to prevent entry or spread of dangerous pests (plant quarantine). According to this, the organization identifies threatening pests and proposes workable phytosanitary measures which can be taken. The list of documents produced by EPPO related to forest pests and commodities, reported in Table 1, include standards for commodity, diagnostic protocols for pests, and standards for pest risk assessment (Box 1).

Box 1. Glossary.

Pest Risk Analysis (PRA)
The PRA consists of the assessment of the probability of entry, establishment, spread, and impact of pests.
Specific guidelines for pest risk analysis (PRA) are provided by the International Plant Protection Convention
(IPPC) in International Standards for Phytosanitary Measures (ISPMs) No 2 [40] and No 11 [41]. The relevant
terminology is included in ISPM No 5 [42].
In recent years, with the aim to improve its standards, EPPO has formalised the identification of risk and the
justification of phytosanitary measures to be taken. Several EPPO Standards on PRA are now available [43].
EPPO has also developed a decision-support scheme for PRA, and a computer program (Computer Assisted
Pest Risk Analysis-CAPRA) [44] to assist pest risk analysts in running the decision-support scheme. A new
method for a quantitative PRA and the identification and evaluation of risk-reducing options is currently under
development by the European Food Safety Authority (EFSA) Plant Health Panel [45]. The method has been
applied to some case studies related to forest plants, including Atropellis spp. [46] and Cryphonectria parasitica [47].
Contingency Plan
The plan is defined to ensure a rapid and effective response to an outbreak of a pest which has been
considered a threat with high economic and environmental impact. It contains information concerning the
decision-making processes, procedures, and protocols to be followed. As specified in International Standards for
Phytosanitary Measures (ISPMs) No. 9 [48], a contingency plan is needed for pests with a high potential of
introduction and for which an eradication plan is deemed necessary. EPPO standards in series PM9- National
regulatory control system provide procedures for control of specific pests with the aim of containing and
eradicating them.
Demarcated Areas

EPPO standards for commodities [49] contain recommendations about phytosanitary measures which should be used or required by EPPO member countries for certain commodities moving in trade, to prevent the introduction and spread of quarantine pests. The EPPO list of forest commodities is provided in Table 1. Additional pest-specific information produced or collected by EPPO is available in the EPPO Global Database [50]. 
Table 1. Documents produced by the European and Mediterranean Plant Protection Organization (EPPO) related to forest pests and commodity [43].

\begin{tabular}{|c|c|c|}
\hline EPPO & Documents & Commodity/Pests \\
\hline \multirow{6}{*}{ Standards } & PM 8/2(2) & Coniferae \\
\hline & $\mathrm{PM} 8 / 4(1)$ & Castanea \\
\hline & PM 8/5(1) & Quercus \\
\hline & PM 8/6(1) & Betula \\
\hline & $\mathrm{PM} 8 / 7(1)$ & Populus \\
\hline & PM 8/8(1) & Salix \\
\hline \multirow{9}{*}{ Diagnostic Protocols } & PM 7/14(2) & Ceratocystis platani \\
\hline & PM 7/45(1) & Cryphonectria parasitica \\
\hline & PM 7/46(3) & Lecanosticta acicola \\
\hline & PM 7/73(1) & Gymnosporangium spp. (non-European) \\
\hline & PM 7/91(1) & Fusarium circinatum \\
\hline & PM7/119(1) & Bursaphelenchus xylophilus (nematode extraction) \\
\hline & PM7/123(1) & Phytophthora lateralis \\
\hline & PM7/112(1) & P. kernoviae \\
\hline & PM7/66(1) & P. ramorum \\
\hline \multicolumn{3}{|c|}{ Final Decision } \\
\hline \multirow{11}{*}{ Pest Risk Analysis } & A1-2011 & Agrilus anxius \\
\hline & A1-2013 & Apriona spp. \\
\hline & A1-2014 & Aromia bungii \\
\hline & A1-2013 & Oemona hirta \\
\hline & A2-2014 & Polygraphus proximus \\
\hline & A2-2015 & Geosmithia morbida \\
\hline & A2-2015 & Heterobasidion irregulare \\
\hline & A1—transferred to A2 in 2011 & Phytophthora lateralis \\
\hline & A2 in 2013 & P. kernoviae and P. ramorum \\
\hline & A2-2017 & Thekopsora minima \\
\hline & A1—transferred to A2 in 2010 & Bursaphelenchus xylophilus \\
\hline
\end{tabular}

The Panel on Plant Health of the European Food Safety Authority (EFSA) provides the European Commission independent scientific advice on the risk posed by plant pests, which can cause harm to plants, plant products, or biodiversity in the EU. Several scientific opinions have been produced on forest pests, including Atropellis spp. [46], Cryphonectria parasitica [47], and many others [51]. The EFSA Panel carries out scientific evaluations of pest risk assessment or evaluates risk mitigating measures proposed by other parties. The EFSA opinions often form the basis for regulation of organisms considered harmful to plants or plant products under the Council Directive 2000/29/EC. This Directive specifies requirements for the trade in plant material (including wood) into and within the European Union.

A scheme of the relationship between phytosanitary organisations is reported in Figure 1. 


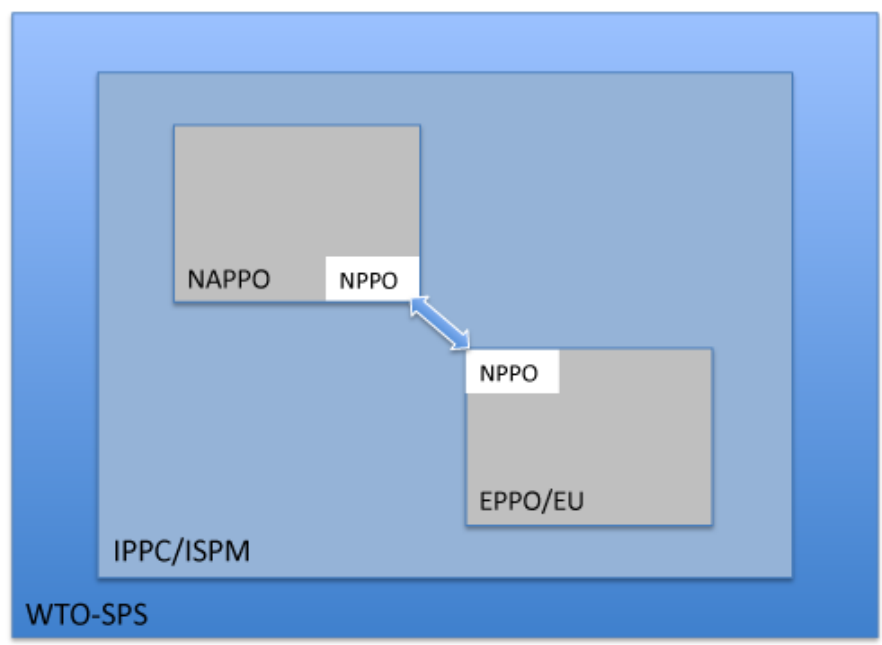

Figure 1. Relationship between phytosanitary organisations as indicated by different coloured boxes; figure adapted from Klapwijk et al., 2016 [52]. Abbreviations. WTO: World Trade Organization, SPS: Agreement on the Application of Sanitary and Phytosanitary Measures, IPPC: International Plant Protection Convention, ISPM: International Standards for Phytosanitary Measures, NAPPO: North American Plant Protection Organisation, NPPO: National Plant Protection Organisation, EPPO: European and Mediterranean Plant Protection Organization.

Within the European Community, plant health was initially a national responsibility. In 1977, member states started to work together to regulate imported plant material and restrict imports where necessary (Plant Health Directive 77/93/EC).

At present, the 28 member states of the European Union (EU) have harmonised phytosanitary legislation as specified by Plant Health Directive 2000/29/EC. This Directive lists about 300 harmful organisms, some of them subjected to specific quarantine requirements, whose introduction into or spread within the EU is prohibited. It establishes control checks to be carried out at the place of origin on plants and plant products destined for the EU, or to be moved within the EU. It also defines the control measures to be carried out at the border of the Community upon arrival of plants and plant products (including wood). Nevertheless, member states can be authorised to provide derogations from certain provision of Council Directive 2000/29/EC regarding plants or plant products listed in Annex III part A and B.

Directive 2000/29/EC is supported by further legislation in the form of a number of Control Directives and Emergency Measures against organisms, which could be introduced into or spread within the Community. Currently, there are five emergency measures in place for pests and diseases endangering European forests (Table 2). 
Table 2. Geographic distribution and status of pests threatening European forests for which emergency measures have been implemented.

\begin{tabular}{|c|c|c|c|c|c|}
\hline \multirow{2}{*}{ Pest/Pathogen } & \multirow{2}{*}{ Group } & \multicolumn{2}{|l|}{ Outbreak Areas } & \multirow{2}{*}{ Description } & \multirow{2}{*}{ EU Decision } \\
\hline & & Present & Transient, under Eradication & & \\
\hline Anoplophora chinensis & Insect & $\begin{array}{l}\text { China (Anhui, Aomen (Macau), Fujian, Gansu, } \\
\text { Guangdong, Guizhou, Hebei, Hubei, Hunan, } \\
\text { Jiangsu, Jiangxi, Liaoning, Shaanxi, Sichuan, } \\
\text { Xinjiang, Xizhang, Yunnan, Zhejiang), EU (Italy), } \\
\text { Indonesia, Japan (Hokkaido, Honshu, Japan } \\
\text { Kyushu, Ryukyu Archipelago, Shikoku), Korea } \\
\text { Dem. People's Republic, Malaysia, Myanmar, } \\
\text { Philippines, Taiwan, Vietnam. }\end{array}$ & $\begin{array}{l}\text { EU (Croatia, Germany), } \\
\text { Switzerland, Turkey }\end{array}$ & \multirow{2}{*}{$\begin{array}{l}\text { The life cycle can be one or two generations per year, } \\
\text { depending on the climatic and feeding conditions. } \\
\text { Adults feed on leaves, petioles, and young bark of } \\
\text { various tree species. The eggs are deposited under the } \\
\text { bark. In international trade, these insects are most likely } \\
\text { to move as eggs, larvae, or pupae hidden in woody } \\
\text { plants and packing material. Larvae and adults of } A \text {. } \\
\text { glabripennis have been intercepted in the United } \\
\text { Kingdom on packaging material, while individuals of } A \text {. } \\
\text { chinensis entered Europe on bonsai plants. Damage to } \\
\text { fruit, and ornamental and amenity trees, results in } \\
\text { serious economic loss. Moreover, attacks on urban } \\
\text { plants poses hazards to pedestrians and vehicles from } \\
\text { structural weakening and falling branches }[53,54] \text {. }\end{array}$} & 2012/138/EU \\
\hline Anoplophora glabripennis & Insect & $\begin{array}{l}\text { China (Anhui, Fujian, Gansu, Guangdong, } \\
\text { Guangxi, Guizhou, Hebei, Heilongjiang, Henan, } \\
\text { Hubei, Hunan, Jiangsu, Jiangxi, Jilin, Liaoning, } \\
\text { Neimenggu, Ningxia, Qinghai, Shaanxi, } \\
\text { Shandong, Shanxi, Sichuan, Xinjiang, Xizhang, } \\
\text { Yunnan, Zhejiang), EU (France-Corsica, } \\
\text { Finland) Korea Dem. People's Republic, } \\
\text { Lebanon, Russia Far East, United States of } \\
\text { America (Ohio, New York). }\end{array}$ & $\begin{array}{l}\text { EU (Austria, France, } \\
\text { Germany, Italy), Canada } \\
\text { (Ontario), Montenegro, } \\
\text { Switzerland, United Kingdom } \\
\text { (England) }\end{array}$ & & 2015/893/EU \\
\hline $\begin{array}{c}\text { Bursaphelenchus xylophilus } \\
\text { (Pine Wood } \\
\text { Nematode-PWN) }\end{array}$ & Nematode & $\begin{array}{l}\text { Canada (Alberta, British Columbia, Manitoba, } \\
\text { New Brunswick, Newfoundland, Northwest } \\
\text { Territories, Nova Scotia, Nunavut, Ontario, } \\
\text { Québec, Saskatchewan, Yukon Territory), China } \\
\text { (Anhui, Chongqing, Fujian, Gansu, Guangdong, } \\
\text { Guangxi, Guizhou, Hubei, Hunan, Jiangxi, } \\
\text { Liaoning, Shandong, Sichuan, Yunnan, Zhejiang, } \\
\text { Xianggang), EU (Portugal), Japan (Honshu, } \\
\text { Kyushu, Ryukyu Archipelago, Shaanxi, Shikoku, } \\
\text { Jiangsu), Korea Republic, Mexico, Taiwan, USA } \\
\text { (Alabama, Arizona, Arkansas, California, } \\
\text { Colorado, Connecticut, Delaware, Florida, } \\
\text { Georgia, Illinois, Indiana, Iowa, Kansas, } \\
\text { Kentucky, Louisiana, Maryland, Massachusetts, } \\
\text { Michigan, Minnesota, Mississippi, Missouri, } \\
\text { Nebraska, New Jersey, New York, North } \\
\text { Carolina, Ohio, Oklahoma, Oregon, } \\
\text { Pennsylvania, South Carolina, Tennessee, Texas, } \\
\text { Vermont, Virginia, West Virginia, Wisconsin). }\end{array}$ & EU (Portugal, Spain) & $\begin{array}{l}\text { Bursaphelenchus xylophilus is the causal agent of the pine } \\
\text { wilt disease. It is transmitted from one host to the next } \\
\text { by insect vectors, mainly belonging to the genus } \\
\text { Monochamus. It enters the tree through wounds caused } \\
\text { by the insect feeding on the twig bark or wounds by the } \\
\text { vector to lay its eggs. Once inside the tree, nematodes } \\
\text { feed on the hyphae of fungi (usually Ceratocystis spp.) } \\
\text { also transmitted to the wood by ovipositing beetles. } \\
\text { They rapidly multiple in the resin canals leading to tree } \\
\text { death within a few months }[55,56] \text {. }\end{array}$ & \\
\hline
\end{tabular}


Table 2. Cont

\begin{tabular}{|c|c|c|c|c|c|}
\hline \multirow{2}{*}{ Pest/Pathogen } & \multirow{2}{*}{ Group } & \multicolumn{2}{|l|}{ Outbreak Areas } & \multirow{2}{*}{ Description } & \multirow{2}{*}{ EU Decision } \\
\hline & & Present & Transient, under Eradication & & \\
\hline Fusarium circinatum & Fungus & $\begin{array}{l}\text { Chile, EU (Portugal, Spain), Haiti, Japan } \\
\text { (Kyushu, Ryukyu Archipelago), Korea Republic, } \\
\text { Mexico, South Africa, Uruguay, USA (Alabama, } \\
\text { Arkansas, California, Florida, Georgia, } \\
\text { Louisiana, Mississippi, North Carolina, South } \\
\text { Carolina, Tennessee, Texas, Virginia). }\end{array}$ & EU (Portugal, Spain) & See section "The case of Fusarium circinatum". & 2007/433/EC \\
\hline Phytophtora ramorum & Chromista & $\begin{array}{l}\text { EU (Denmark, Germany, Greece, Poland, } \\
\text { Portugal, Serbia, Spain, Belgium, Croatia, } \\
\text { France, Ireland, Netherlands, Norway, Sweden, } \\
\text { United Kingdom-Channel Islands, England, } \\
\text { Scotland) Switzerland, Canada-British } \\
\text { Columbia, USA (Florida, Georgia, Louisiana, } \\
\text { South Carolina, Tennessee, Washington, Virginia, } \\
\text { California, Oregon). }\end{array}$ & $\begin{array}{l}\text { EU (Czech Republic, Finland, } \\
\text { Italy, Slovenia). }\end{array}$ & $\begin{array}{l}\text { Phytophthora ramorum is an oomycete pathogen known } \\
\text { as responsible agent of sudden oak disease (SOD). } \\
\text { The disease causes extensive damage and death to a } \\
\text { wide range of trees and ornamental plants. It resulted in } \\
\text { significant losses of trees, mainly oaks in California and } \\
\text { Oregon. By contrast, in Europe, the pathogen affects } \\
\text { mainly ornamental shrubs. However, recently, } P \text {. } \\
\text { ramorum was unexpectedly detected on Japanese larches } \\
\text { (Larix kaempferi), causing widespread tree mortality in } \\
\text { England. } P \text {. ramorum produces several types of } \\
\text { structures (zoospores, sporangia, and chlamydospores) } \\
\text { specialised for survival, dispersal, or infection. } \\
\text { Movement of infected ornamental shrubs is a significant } \\
\text { mode of dispersal. The disease can be transmitted by } \\
\text { infected plants and soil, and dispersal through vectors } \\
\text { and air/water is still poorly understood [57-59]. }\end{array}$ & 2002/757/EC \\
\hline
\end{tabular}


In 2019, a new Plant Health Regulation (Directive 2016/2031) will be implemented. The new regulation focuses particularly on the prevention of entry or spread of plant pests within the EU territory. According to this Directive, a list of priority pests, with significant severe economic, social, and environmental effects will be defined. For these priority pests, member states are obliged to perform annual detection surveys and to develop contingency plans that contain detailed descriptions of the actions to be taken in case of an outbreak.

\subsection{The Case of Fusarium circinatum}

Fusarium circinatum causes pine pitch canker (PPC) disease, one of the most devastating diseases in Pinus spp. in several countries worldwide (Figure 2) [60].

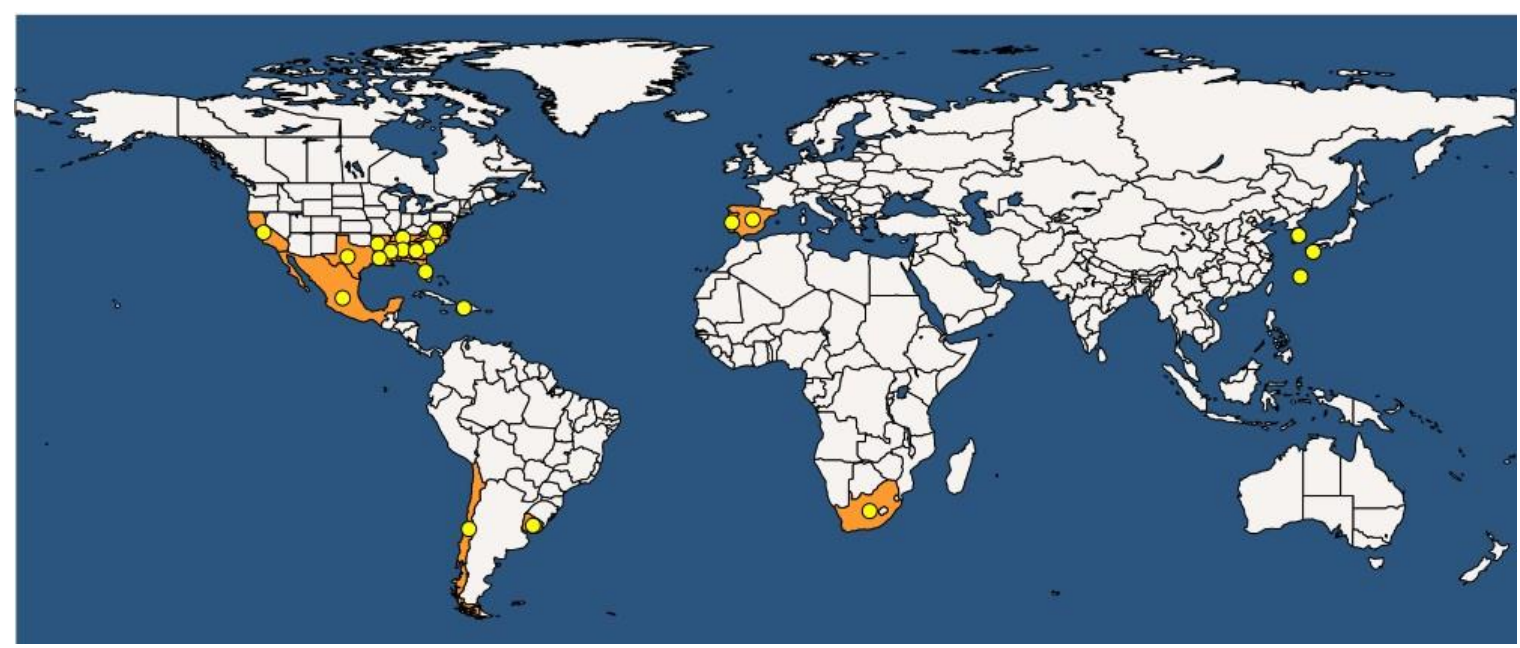

Figure 2. World map of the current distribution of Fusarium circinatum represented by yellow dots [50].

PPC disease shows characteristic sunken cankers that produce abundant resin in branches and main stem (Figure 3).

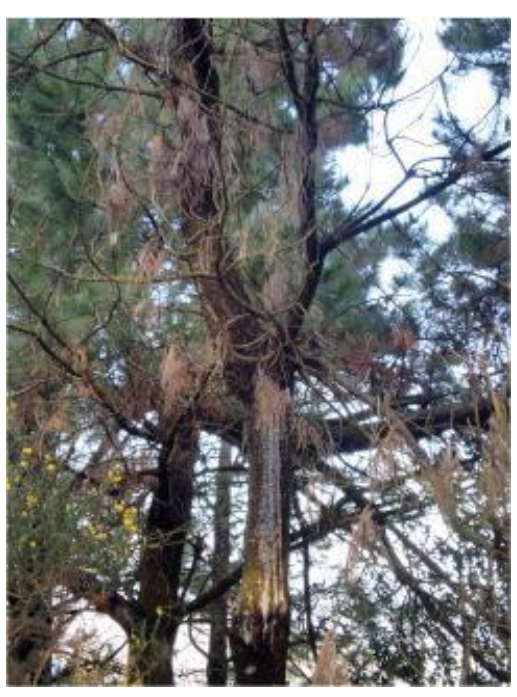

(a)

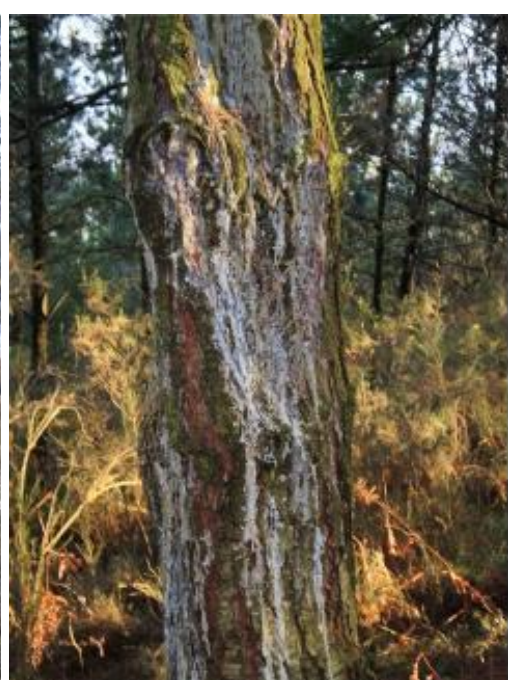

(b)

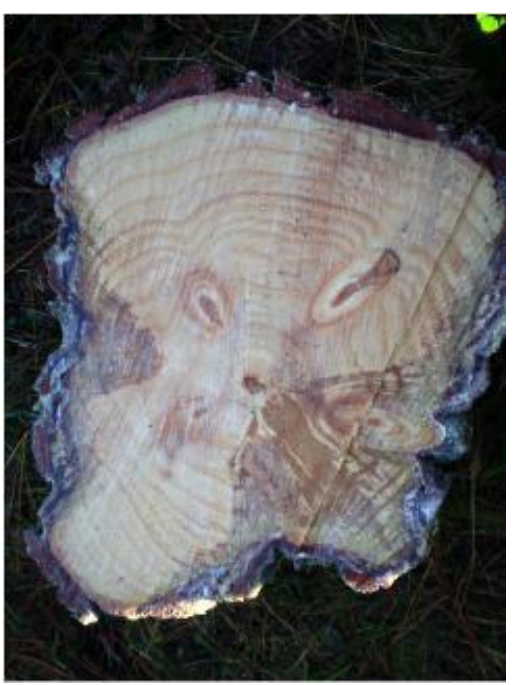

(c)

Figure 3. Symptoms of pine pitch canker disease on mature trees: (a) infected tree showing branch symptoms and resin flow at on the stem, (b) resinous canker on the main stem, (c) canker section.

Above the infection point, needles are brown and necrotic, causing partial discoloration and defoliation of branches which appears as dieback. There are usually multiple infection points in a 
tree that may cause severe canopy defoliation. In seedlings, the pathogen causes damping-off in pre- and post-emergence. All Pinus species and Pseudotsuga menziesii can be affected by the disease, but these species vary widely in susceptibility. The most susceptible species are $P$. radiata [61,62] and $P$. patula [63], and the least susceptible species are P. thunbergii, P. canariensis, and P. pinea [60]. In Europe, the pathogen has been found in forest stands of $P$. pinaster and P. radiata in Spain [64,65], and $P$. radiata in Portugal [66], and in association with different Pinus species in nurseries [64,66]. The pathogen was eradicated in urban parks on P. halepensis and P. pinea [67] in Italy, and on P. menziesii and Pinus spp. trees in French nurseries [68].

In 2005, PPC disease was reported in P. radiata in Spain, as the first detection in Europe [69]. Hereafter, there were other disease occurrences reported in Italy [67] and France (NPPO, 2011) that were eradicated. Today, the disease is established in several new areas in Spain and Portugal [70] (Figure 4).

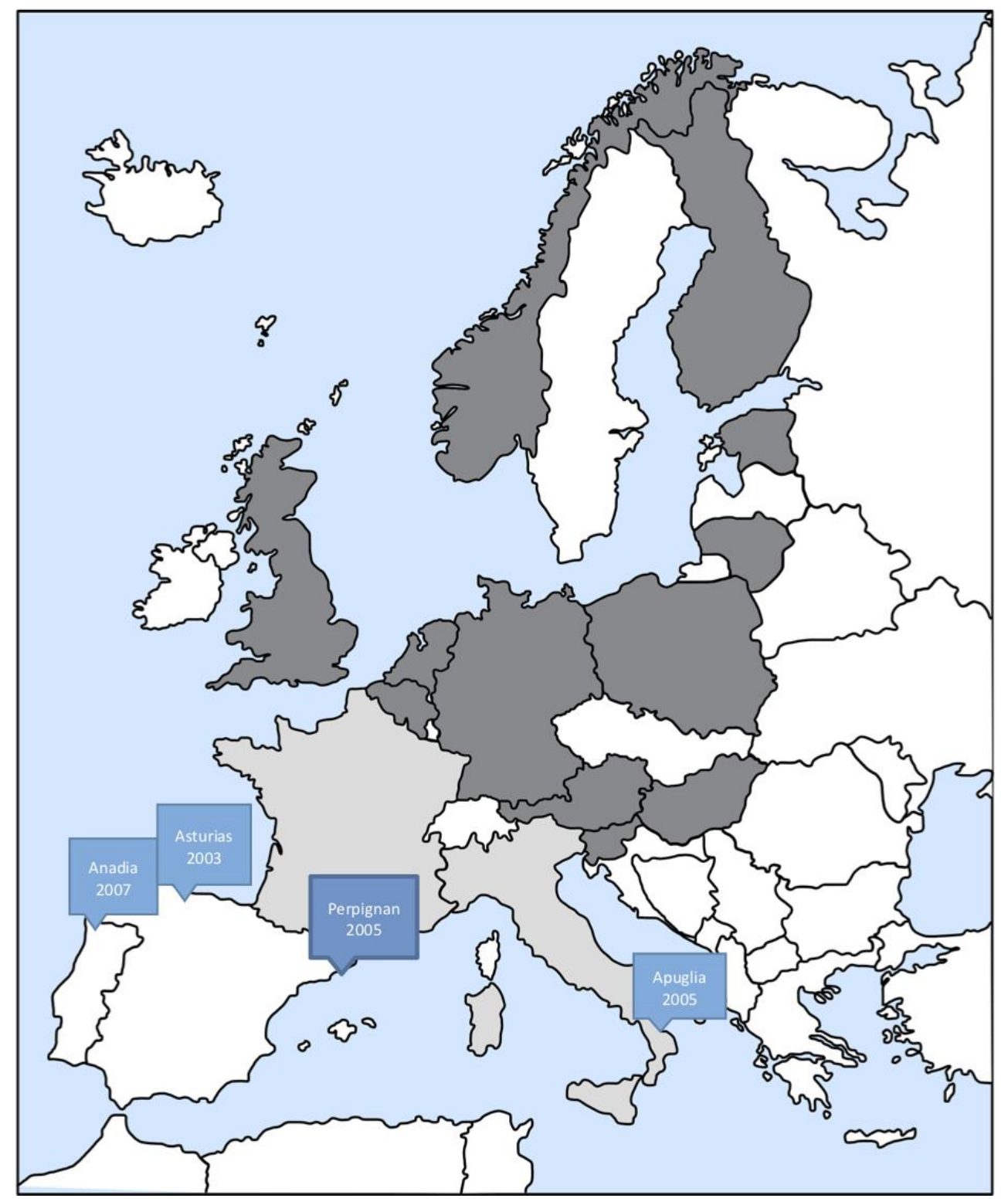

Figure 4. Year and location of first reports of Fusarium circinatum in countries within the European Union according to EPPO [70]. White = no information available, Light grey $=$ pest absent, eradicated; grey $=$ pest absent, confirmed by survey, black = pest present. 
The occurrence of PPC is in agreement with suitable areas defined by the species distribution model CLIMEX for potential PPC disease establishment, that include zones within Europe in Portugal, Spain, France, Italy, and Greece [71]. Fusarium circinatum spreads via spores disseminated by air and insects, which are produced throughout the year [72]. Successful natural infections are associated with wounds (mechanical, weather-related, and insect-mediated activity) under favourable environmental conditions. The relative importance of dispersing the pathogen by insects and spores is variable. Insects are considered the most important means of dissemination in California [60]. In Spain, fungal spores have been detected both in the air throughout the year and associated with bark beetles such as Tomycus piniperda and Pityophthorus pubescens $[73,74]$. The pathogen can be brought to new areas mainly by seeds, seedlings, soil, and plant material. Pine seeds and seedlings are considered the major pathways of introduction into new countries.

Fusarium circinatum may infest seeds superficially, and internally colonise the embryo and the gametophyte tissues. Proportions of infested P. radiata seeds in California and Spain are $83 \%$ and $0.73 \%$, respectively. However, these infections appear to be superficial [75]. In forest nurseries, F. circinatum causes damping-off of seedlings, but under certain unknown conditions, seedlings can be asymptomatic, and then become an important means of dispersion. Fusarium circinatum can also be disseminated by movement of soil. The pathogen survives in infested debris on the soil surface for up two years, but not in soil [76]. This is more likely due to the lack of survival structures and low inoculum potential. Serrano et al. (2017) indicated that the number of surviving F. circinatum spores in soil is high for a short time. This finding provides additional evidence that the pathogen may persist in soil long enough to be regarded as a vehicle for spreading to new areas [76]. In addition, F. circinatum can overwinter in infected branches and logs from which insect vectors can emerge and spread the pathogen. The association of the pathogen with insects is particularly worrying when firewood or infested plant material are moved to new areas [60].

\subsubsection{EU Legislation}

Fusarium circinatum is included in the EPPO A2 list (pests locally present in the EPPO region) and is regulated as a quarantine pest in the EU, as specified in the emergency measures (Commission Decision 2007/433/EC). Although not specific to F. circinatum, some provisions of the EU plant Health Directive are also relevant in order to prevent the introduction and spread of $F$. circinatum in the EU, in particular:

- Annex III (A), prohibits the introduction of plants or plant parts of Pinus spp. and Pseudotsuga menziesii (host plants) other than fruit and seed from non-European countries in all member states. Annex III (A) also prohibits the introduction of soil and growing medium as such in all member states;

- Annex II (A) and IV(A) specify import requirements for growing media attached to plants and coniferous wood;

- Wood packaging material must comply with the requirements as specified in ISPM 15.

Requirements for marketing of pine reproductive material (seeds, parts of plants, and planting stock) are also included in the Council Directive 1999/105/EC11, issued for marketing of forest reproductive material and its implementing measures.

\subsubsection{Emergency Measures and Contingency Plans}

Since the reported outbreaks in Spain, there are now emergency measures in place to prevent the introduction into and the spread within the EU of F. circinatum (Commission Decision 2007/433/EC). This EU decision imposes requirements on the import and internal movement of plants of Pinus spp. and P. menziesii intended for planting, including seeds and cones for propagation purposes (see Box 2 for details). The EU decision also sets survey obligations to EU member states and indicates which measures should be taken by member states when the organism is found. It is worth noting that, at the time that the EU measures were instituted, it was not yet known that the fungus could infect herbaceous plants. Natural infection of grasses (Briza maxima, Ehrharta erecta var. 
erecta, Pentameris pallida, and one unidentified species) was published for the first time in 2012 [24]. Recently, F. circinatum has been isolated from non-symptomatic plant species belonging to the Asteraceae, Lamiaceae, Rosaceae, and Poaceae families, and from Hypochaeris radicata seeds [25]. The role these herbaceous plants may have in the general life cycle of the pathogen still needs to be elucidated. Preliminary results suggest that these plants become infected from airborne spores released from pine cankers. Knowledge regarding the relative contribution of this potential inoculum source, as well as its survival time once trees are felled, requires further studies.

Box 2. Outline of European Unit Emergency Measures against Fusarium circinatum as specified in 2007/433/EC.

\section{(A) Specific Import Requirements for Specified Plants}

The movement of specified plants originating in third countries has to be accompanied by a certificate stating that the specified plants originate in a place of production which is registered and supervised by the national plant protection organisation in the country of origin, and

(i) they have been grown throughout their life in countries where the specified organism is not known to occur, or

(ii) they have been grown throughout their life in a pest-free area, established by the national plant protection organisation in the country of origin in accordance with relevant International Standards for Phytosanitary Measures. The name of the pest-free area shall be mentioned under the rubric "place of origin", or

(iii) they originate in a place of production where no signs of the specified organism have been observed during official inspections within a period of two years prior to export, and have been tested immediately prior to export.

(B) Conditions for EU Internal Movement of Specified Plants

All specified plants either originating in the Community or imported into the Community may be moved within the Community only if they are accompanied by a plant passport, and

(i) they have been grown throughout their life or since their introduction into the Community in a place of production of a Member State where the organism is not known to occur, or

(ii) they have been grown throughout their life or since their introduction into the Community, in a place of production in a pest-free area, established by the responsible official body in a Member State, in accordance with relevant International Standards for Phytosanitary Measures, or

(iii) they originate in a place of production where no signs of the specified organism have been observed during official inspections within a period of two years prior to movement and have been tested immediately prior to movement.

(C) Establishment of Demarcated Areas (Box 1)

The Commission Decision 2007/433/EC further requires the establishment of demarcated areas following introduction of the pathogen. The demarcated areas consist of the following parts:

(i) an infected zone where the presence of the specified organism has been confirmed and which includes all specified plants showing symptoms caused by the specified organism, and

(ii) a buffer zone with a boundary at least $1 \mathrm{~km}$ beyond the infected zone. In cases where several buffer zones overlap or are geographically close, a wider demarcated area shall be defined which includes the relevant demarcated areas and the areas between them.

The official measures to be taken in the demarcated areas must include at least

(i) appropriate measures aimed at eradicating the specified organism;

(ii) intensive monitoring (surveillance) for the presence of the specified organism through appropriate inspections.

(D) Surveys and Notifications

Member states shall conduct official annual surveys for the presence of the specified organism or evidence of infection by this organism in their territory. The results of these surveys must be reported each year. If the pathogen is detected, control measures involve setting up a buffer zone of at least $1 \mathrm{~km}$ around the contamination point, and carrying out an intensive survey and extermination measures within the demarcated area. If the organism is no longer found for two consecutive years, the measures may be discontinued.

Note: "specified plants" means plants of the genus Pinus L. and the species P. menziesii, intended for planting, including seeds and cones for propagation purposes. 
A strategy successful in controlling and eradicating F. circinatum should be developed at an international level. It should include contingency plans and clear governance to minimise/eradicate the impact when outbreaks occur. From 2019, the development of contingency plans will be mandatory for all member states with the application of the Directive 2016/2031. According to this Directive, each contingency plan shall include the following:

(a) the roles and responsibilities of the bodies involved in the execution of the plan in the event of an outbreak;

(b) access of competent authorities to premises of operators, laboratories, equipment, personnel, external expertise and resources necessary for the rapid and effective eradication or containment of the priority pest;

(c) official publication and communication of findings and measures taken against the priority pest;

(d) a pest risk assessment regarding the risk of the priority pest concerned for its territory and the risk management measures to be taken;

(e) principles for the geographical demarcation of demarcated areas;

(f) protocols describing the methods of visual examinations, sampling and laboratory testing, and principles concerning the training of personnel.

Contingency plans may be combined for multiple priority pests with similar biology and range of host species.

Recently, EPPO developed the standard generic elements for contingency plans and new standards for important pests in the series PM 9 National Regulatory Control Systems. This should facilitate EPPO members to draft their own pest-specific contingency plans and harmonizing the strategies for control and eradication of dangerous pests in Europe.

Presently few European countries have designed a strategy to help government agencies to anticipate, assess, prepare for, prevent, or respond to and recover from $F$. circinatum outbreaks, regardless of the presence of positive records of the pathogen. In the United Kingdom, F. circinatum is not known to be present. However, it is listed on the UK Plant Health Risk Register with a high unmitigated risk rating of 75/125, and a low mitigated risk rating of 50/125. In 2016, a contingency plan was prepared by the Forestry Commission's cross-border Plant Health Service to be used at country and national levels [77]. This contingency plan contains information on official actions following presumptive diagnosis and outbreak and background information about the pest. In addition, as required by EC decision 2007/433/EC, an annual survey of $P$. radiata (considered to be the most susceptible pine species) is carried out in England and Wales. The survey is not conducted in Scotland because there are no P. radiata stands there, and the climate is not as suitable as in other British regions. Moreover, the Forestry Commission in England has also published a pest alert and a field guide to identifying the symptoms of pine pitch canker.

In Spain, the disease still represents a serious threat to pine forests and nurseries. It is under eradication in some areas. The law RD 637/2006, partially modified in RD65/2010, regulates the eradication and control of $F$. circinatum in Spain. The directive contains essential elements of a contingency plan, as recommended by ISPM No. 9 [9]. A detailed comparison for contingency plans defined in UK (with no positive records of disease) and Spain is given in Table 3. Both plans address practically the same cases and situations, although the Spanish laws are more detailed, probably because they were enacted when PPC disease was already present in the country. 
Table 3. Comparison of contingency plans of Fusarium circinatum as defined in United Kingdom [77] and Spain ${ }^{\mathrm{a}}$.

\begin{tabular}{|c|c|}
\hline United Kingdom & Spain \\
\hline \multicolumn{2}{|l|}{ Obligations within Demarcated Areas } \\
\hline $\begin{array}{l}\text { Trees felled to eradicate F. circinatum should be } \\
\text { destroyed in situ. }\end{array}$ & All susceptible plants in the infected zone should be destroyed in situ. \\
\hline $\begin{array}{l}\text { For nurseries in the area, authorization for Pinus and } \\
\text { Douglas fir plants suspended until the presence of } F \text {. } \\
\text { circinatum within the nursery and within the } \\
\text { demarcated area is determined. }\end{array}$ & $\begin{array}{l}\text { For forest reproductive material, all fields and facilities that use this } \\
\text { material will be declared as possibly contaminated and, therefore, } \\
\text { susceptible plant material is to be eliminated and facilities } \\
\text { decontaminated. Particularly for seeds, the affected batch will be } \\
\text { destroyed, and all other batches that share facilities will be declared as } \\
\text { possibly contaminated and immobilised until presence of F. circinatum } \\
\text { is determined. }\end{array}$ \\
\hline \multicolumn{2}{|c|}{ After immediate measures taken, possible preventive measures to be applied are described. } \\
\hline \multicolumn{2}{|l|}{ Tracing Backwards } \\
\hline $\begin{array}{l}\text { If the infected trees have been planted within the } \\
\text { previous two years, the source of the plants must be } \\
\text { traced back to the supplying nursery, and the nursery } \\
\text { inspected for the presence of } F \text {. circinatum. }\end{array}$ & $\begin{array}{l}\text { The origin of affected plants within a planted forest will be } \\
\text { investigated to determine the possible source of plants. Suppliers of } \\
\text { infected forest reproductive material will provide a list with users of } \\
\text { that material in the last two years. Material will be immobilised and } \\
\text { analysis will be done to determine the presence of F. circinatum. }\end{array}$ \\
\hline $\begin{array}{l}\text { If the infected trees have been planted within the } \\
\text { previous two years, the source of the plants must be } \\
\text { traced back to the supplying nursery, and the nursery } \\
\text { inspected for the presence of } F \text {. circinatum. }\end{array}$ & $\begin{array}{l}\text { Origin of affected plants within a planted forest will be investigated to } \\
\text { determine the possible source of plants. Suppliers of infected forest } \\
\text { reproductive material will provide a list with users of that material in } \\
\text { the last two years. Material will be immobilised and analysis will be } \\
\text { done to determine the presence of F. circinatum. }\end{array}$ \\
\hline \multicolumn{2}{|c|}{ Disposal of Felled Trees (Including Branches and Round Wood) } \\
\hline $\begin{array}{l}\text { By chipping, composting or burning. Regulations for } \\
\text { burning are explained }\end{array}$ & By burning or any other accepted method. \\
\hline \multicolumn{2}{|c|}{$\begin{array}{l}\text { Plant material for decorative purposes, particularly material used for Christmas trees, should be preferably buried or } \\
\text { composted. }\end{array}$} \\
\hline $\begin{array}{l}\text { In nurseries, infected plants and seedlings should be } \\
\text { uprooted and burned. }\end{array}$ & Infected plants and seedlings have to be eliminated; way not specified. \\
\hline \multicolumn{2}{|l|}{ Movement of Plant Material from Demarcated Areas } \\
\hline $\begin{array}{l}\text { It is not recommended that logs and firewood cut in } \\
\text { infested areas be moved from the demarcated area. }\end{array}$ & $\begin{array}{l}\text { It is forbidden to move plants and plant material (including wood) out } \\
\text { from the demarcated areas. }\end{array}$ \\
\hline $\begin{array}{l}\text { If logs must be moved, debarking is recommended. } \\
\text { They should be transported, with a protective } \\
\text { covering ensuring that all material is contained, to a } \\
\text { licensed incinerator. Merchantable logs may be sold } \\
\text { to an authorised processing plant within the } \\
\text { demarcated area for conversion to products such as } \\
\text { pulp or fibreboard. Their use as saw logs is not } \\
\text { allowed. }\end{array}$ & $\begin{array}{l}\text { An exception is made for wood and wood products (first } \\
\text { transformation) if it is completely debarked, a heat treatment is } \\
\text { applied in a way that inner wood reaches at least } 56^{\circ} \mathrm{C} \text { for } 30 \mathrm{~min} \text {, } \\
\text { and it has its phytosanitary passport. If the wood requires } \\
\text { transportation because there are no facilities to treat it within the } \\
\text { demarcated area, it has to be done under supervision. }\end{array}$ \\
\hline
\end{tabular}

a Spanish laws RD 65/2010 and RD637/2006 for eradication and control of F. circinatum.

\section{Conclusions}

Forest ecosystems can be seriously affected by both intentional and unintentional invasions. In the last decade, along with rising global awareness of the impact of invasive forest pathogens, there has been growing recognition within the international community for the need to develop actions required for prevention and control, including legislation frameworks. To date, the European Union's response to the problems of alien species has been developed within international agreements, such as the World Trade Organization Agreement on the Application of Sanitary and Phytosanitary Measures (SPS), and the Convention on Biological Diversity (CBD). Nevertheless, the number of IAS' establishment in Europe has progressively increased over the last century [2-4]. Current legislations are based on the consensus amongst scientists and policy-makers that prevention is better than cure. However, there are gaps in the international regulatory framework that weaken the system. The new Directive 2016/2031 provides a solid legislative basis for the EU response to IAS. It also puts forward several concrete measures to tackle them as trade bans, restrictions on intentional release and contingency 
plans. Nevertheless, several aspects still need to be optimised in addressing the IAS problem. Some of them are particularly noteworthy. The core instrument of the EU regulation is the European Union "blacklist", based on already-known pests [78]. Currently, the EPPO and the EFSA carry out pathway risk analyses for some of them. Nonetheless, many new non-native pests were previously unknown to be harmful, or even to science, and were therefore not regulated before they invaded. To address this issue, monitoring of sentinel plants in exporting countries has been proposed as a valuable tool to identify harmful organisms prior to their arrival [79-81]. Although several European projects (e.g., ISEFOR, COST Action FP1401, EUPHRESCO, IPSN, PRATIQUE) highlight the use of sentinel plantations, arboreta, and botanical gardens as an effective method for the identification of potential plant threats, as of now, no EU regulations are specifically defined for their implementation. This can lead to a discouraging complex bureaucracy which, in turn, discourages sentinel plantations. It is worth noting that the list of the pests regulated in the EU contains a different number and different types of organisms than those of other countries [31].

Under the new Directive, priority pests will be subjected to enhanced measures, including surveys, eradication action plans, and contingency plans. According to the new EU Plant Health Directive (article 42) import bans can be introduced for high-risk plants and plant products based on a preliminary assessment to be followed by a full risk assessment. The specific list of high-risk plants is scheduled to be published in December 2018. Another issue that is still poorly considered is the discrepancy between regulations and inspection practices in EU importing countries. In the European Union, all incoming consignments must be inspected at the first "point of entry", but the large differences in the volume of imported plants in member states, the intensity of sampling methods used for inspections, and the generally limited number of inspectors may result in differences in the way inspections are carried out [82]. In conclusion, better regional cooperation and consistency of prevention and mitigation attempts between neighbouring countries are necessary.

International collaboration may contribute to determining likely points of system failures and how to monitor and mitigate such failures.

Concerning specifically $F$. circinatum, there is still a lack of knowledge regarding potential pathways that need to be addressed. Branches for decorative purposes, bark for gardening, and timber, are common items in international trade for which it is unknown how long the pathogen can survive for during transportation and movement. It is also important to raise public awareness of the full consequences of their actions as, for example, the import of pine seeds via the internet, is currently not well regulated by the EU Directive. Moreover, the regional cooperation between Spain and Portugal, highly experienced member states concerning pitch canker disease, and other European countries should be strengthened, increasing exchanges and networking activities between scientific institutions and relevant authorities.

Author Contributions: All authors contributed equally to the study and the revision of the manuscript.

Funding: This research received no external funding.

Acknowledgments: This article is based upon work from COST Action FP1406, Pine pitch canker-Strategies for management of Gibberella circinata in greenhouses and forests (PINESTRENGTH), supported by COST (European Cooperation in Science and Technology). Assistance received from Robert Wick, Stockbridge School of Agriculture, University of Massachusetts, is thankfully acknowledged. We would like to acknowledge anonymous reviewers whose comments and feedback helped a lot to improve the paper.

Conflicts of Interest: The authors declare no conflict of interest. 


\section{References}

1. Convention on Biological Diversity. What Are Invasive Alien Species? Available online: https://www.cbd. int/invasive/WhatareIAS.shtml (accessed on 18 June 2018).

2. Santini, A.; Ghelardini, L.; De Pace, C.; Desprez-Loustau, M.L.; Capretti, P.; Chandelier, A.; Cech, T.; Chira, D.; Diamandis, S.; Gaitniekis, T.; et al. Biogeographical patterns and determinants of invasion by forest pathogens in Europe. New Phytol. 2013, 197, 238-250. [CrossRef] [PubMed]

3. Roques, A.; Rabitsch, W.; Rasplus, J.-Y.; Lopez-Vamonde, C.; Nentwig, W.; Kenis, M. Alien terrestrial invertebrates of Europe. In Handbook of Alien Species in Europe; Delivering Alien Invasive Species Inventories for Europe (DAISIE), Ed.; Springer: Dordrecht, The Netherlands, 2009; pp. 63-79.

4. Desprez-Loustau, M.-L. The alien fungi of Europe. In Handbook of Alien Species in Europe; Delivering Alien Invasive Species Inventories for Europe (DAISIE), Ed.; Springer: Dordrecht, The Netherlands, 2009; pp. 15-28.

5. Liebhold, A.; Brockerhoff, E.; Garrett, L.; Parke, J.; Britton, K. Live plant imports: The major pathway for the forest insect and pathogen invasions of the US. Front. Ecol. Environ. 2012, 10, 135-143. [CrossRef]

6. Eschen, R.; Holmes, T.; Smith, D.; Roques, A.; Santini, A.; Kenis, M. Likelihood of establishment of tree pests and diseases based on their worldwide occurrence as determined by hierarchical cluster analysis. For. Ecol. Manag. 2014, 315, 103-111. [CrossRef]

7. Brasier, C.M. The biosecurity threat to the UK and global environment from international trade in plants. Plant Pathol. 2008, 57, 792-808. [CrossRef]

8. Gonthier, P.; Anselmi, N.; Capretti, P.; Bussotti, F.; Feducci, M.; Giordano, L.; Honorati, T.; Lione, G.; Luchi, N.; Michelozzi, M.; et al. An integrated approach to control the introduced forest pathogen Heterobasidion irregulare in Europe. Forestry 2014, 87, 471-481. [CrossRef]

9. EPPO. Situation of Diabrotica virgifera in Serbia (YU). In Proceedings of the International Workshop "Western Corn Rootworm in Europe 95", Gödöllö, Hungary, 8 November 1995.

10. Aukema, J.E.; McCullough, D.G.; Von Holle, B.; Liebhold, A.M.; Britton, K.; Frankel, S.J. Historical accumulation of non indigenous forest pests in the Continental United States. Bioscience 2010, 60, 886-897. [CrossRef]

11. Aukema, J.E.; Leung, B.; Kovacs, K.; Chivers, C.; Britton, K.O.; Englin, J.; Frankel, S.J.; Haight, R.G.; Holmes, T.P.; Liebhold, A.M.; et al. Economic Impacts of Non-Native Forest Insects in the Continental United States. PLoS ONE 2011, 6, E24587. [CrossRef] [PubMed]

12. Mota, M.; Braasch, H.; Bravo, M.A.; Penas, A.C.; Burgermeister, W.; Metge, K.; Sousa, E. First report of Bursaphelenchus xylophilus in Portugal and in Europe. Nematology 1999, 1, 727-734. [CrossRef]

13. Abelleira, A.; Picoaga, A.; Mansilla, J.P.; Aguin, O. Detection of Bursaphelenchus xylophilus, causal agent of pine wilt disease on Pinus pinaster in North-western Spain. EPPO Bull. 2011, 39, 344-353. [CrossRef]

14. Fonseca, L.; Lopes, A.; Cardoso, J.; Pestana, M.; Abreu, F.; Nunes, N.; Mota, M.; Abrantes, I. The pinewood nematode, Bursaphelenchus xylophilus, in Madeira Island. Helminthologia 2012, 49, 96-103. [CrossRef]

15. Robertson, L.; Arcos, C.S.; Escuer, M.; Merino, S.R.; Esparrago, G.; Abelleira, A.; Navas, A. Incidence of the pinewood nematode Bursaphelenchus xylophlius Steiner \&Buhrer, 1934 (Nickle, 1970) in Spain. Nematology 2011, 13, 755-757. [CrossRef]

16. Rodrigues, J. Eradication program for the pinewood nematode in Portugal. In Pine wilt Disease: A Worldwide Threat to Forest Ecosystems; Mota, M., Vieira, P., Eds.; Springer: Heidelberg, Germany, 2008; pp. 5-14.

17. FVO_Food and Veterinary Office. Final Report of a Mission Carried Out in Portugal from 02 June to 06 June 2008 in Order to Assess the Implementation of Commission Decision 2006/133/Ec and the National Eradication Programme for Bursaphelenchus xylophilus (Pine Wood Nematode); DG SANCO/2008/7991-MR-Final, European Commission. 2008. Available online: https:/ / ec.europa.eu/food/sites/food/files/plant/docs/ph_biosec_legis_ em-measures_pwn-task-force_en.pdf (accessed on 18 June 2018).

18. Soliman, T.; Mourits, M.C.M.; van der Werf, W.; Hengeveld, G.M.; Robinet, C.; Lansink, A.G.J.M.O. Framework for modelling economic impacts of invasive species, applied to pine wood nematode in Europe. PLoS ONE 2012, 7, E45505. [CrossRef] [PubMed]

19. Økland, B.; Skarpaas, O.; Schroeder, M.; Magnusson, C.; Lindelow, A.; Thunes, K. Is eradication of the Pinewood Nematode (Bursaphelenchus xylophilus) likely? An evaluation of current contingency plans. Risk Anal. 2010, 30, 1424-1439. [CrossRef] [PubMed] 
20. Mascheretti, S.; Croucher, P.J.P.; Vettraino, A.M.; Prospero, S.; Garbelotto, M. Reconstruction of the sudden oak death epidemic in California through microsatellite analysis of the pathogen Phytophtho raramorum. Mol. Ecol. 2008, 11, 2755-2768. [CrossRef] [PubMed]

21. Ivors, K.; Garbelotto, M.; Vries, I.; Ruyter-Spira, C.; Hekkert, B.; Rosenzweig, N.; Bonants, P. Microsatellite markers identify three lineages of Phytophtho raramorum in US nurseries, yet single lineages in US forest and European nursery populations. Mol. Ecol. 2006, 15, 1493-1505. [CrossRef] [PubMed]

22. Kanaskie, A.; Hansen, E.M.; Goheen, E.M.; McWilliams, M.; Reeser, P.; Sutton, W. Phytophtho raramorum in Oregon forests: Six years of detection, eradication, and disease spread. In Proceedings of the Fourth Meeting of the International Union of Forest Research Organizations (IUFRO) Working Party S07.02.09: Phytophthoras in Forests and Natural Ecosystems. Gen. Tech. Rep. PSW-GTR-221; Department of Agriculture, Forest Service, Pacific Southwest Research Station: Albany, CA, USA, 2009; pp. 170-172.

23. Haack, R.A.; Herard, F.; Sun, J.; Turgeon, J.J. Managing invasive populations of Asian Longhorned Beetle and Citrus Longhorned Beetle: A worldwide perspective. Ann. Rev. Entomol. 2010, 55, 521-546. [CrossRef] [PubMed]

24. Swett, C.L.; Gordon, T.R. First report of grass species (Poaceae) as naturally occurring hosts of the pine pathogen Gibberella circinata. Plant Dis. 2012, 96, 908. [CrossRef]

25. Hernandez-Escribano, L.; Iturritxa, E.; Elvira-Recuenco, M.; Berbegal, M.; Campos, J.A.; Renobales, G.; García, I.; Raposo, R. Herbaceous plants in the understory of a pitch canker-affected Monterey pine plantation are endophytically infected with Fusarium circinatum. Fungal Ecol. 2018, 32, 65-71. [CrossRef]

26. Sutherland, W.J.; Bailey, M.J.; Bainbridge, I.P.; Brereton, T.; Dick, J.T.A.; Drewitt, J.; Dulvy, N.K.; Dusic, N.R.; Freckleton, R.P.; Gaston, K.J.; et al. Future novel threats and opportunities facing UK biodiversity identified by horizon scanning. J. Appl. Ecol. 2008, 45, 821-833. [CrossRef]

27. Sutherst, R.W.; Baker, R.H.A.; Coakley, S.M.; Harrington, R.; Kriticos, D.J.; Scherm, H. Pests under global change-Meeting your future landlords. In Terrestrial Ecosystems in a Changing World; Canadell, J.G., Pataki, D.E., Pitelka, L.F., Eds.; Springer: Berlin, Germany, 2007; pp. 211-226.

28. Ghini, R.; Hamada, E.; Bettiol, W. Climate change and plant diseases. Sci. Agric. 2008, 65, 98-107. [CrossRef]

29. MacLeod, A.; Pautasso, M.; Jeger, M.J.; Haines-Young, R. Evolution of the international regulation of plant pests and challenges for future plant health. Food Secur. 2010, 2, 49-70. [CrossRef]

30. WTO-SPS. Agreement on the Application of Sanitary and Phytosanitary Measures; World Trade Organization: Rome, Italy, 1995.

31. Eschen, R.; Britton, K.; Brockerhoff, E.; Burgess, T.; Dalley, V.; Epanchin-Niell, R.S.; Gupta, K.; Hardy, G.; Huang, Y.; Kenis, M.; et al. International variation in phytosanitary legislation and regulations governing importation of plants for planting. Environ. Sci. Policy 2015, 51, 228-237. [CrossRef]

32. International Plant Protection Convention (IPPC). Available online: https://www.ippc.int (accessed on 18 June 2018).

33. International Plant Protection Convention (IPPC). ISPM No. 15. Guidelines for regulating wood packaging material in international trade. In International Standards for Phytosanitary Measures; FAO: Rome, Italy, 2006.

34. International Plant Protection Convention (IPPC). ISPM No. 38 on the International Movement of Seed. In International Standards for Phytosanitary Measures; FAO: Rome, Italy, 2017.

35. International Plant Protection Convention (IPPC). ISPM 39. In International movement of wood. In International Standards for Phytosanitary Measures; FAO: Rome, Italy, 2017.

36. Ebbels, D.L.; King, J.E. Plant Health: The Scientific Basis for Control of Plant Diseases and Pests; Blackwell Scientific Pubs.: Oxford, UK, 1979; 322p.

37. International Plant Protection Convention (IPPC). ISPM 36-Integrated Measures for Plants for Planting. ISPM no. 36. In International Standards for Phytosanitary Measures; FAO: Rome, Italy, 2012.

38. NAPPO. RSPM 24-Integrated Pest Risk Management Measures for the Importation of Plants for Planting into NAPPO Member Countries. NAPPO: Ontario, Canada, 2013; Available online: http:/ / www.nappo.org/english/ products/regional-standards/regional-phytosanitary-standards-rspms / (accessed on 18 June 2018).

39. European Plant Protection Organization (EPPO). Available online: https://www.eppo.int/ (accessed on 18 June 2018).

40. International Plant Protection Convention (IPPC). ISPM 2-Framework for Pest Risk Analysis. ISPM No. 2. In International Standards for Phytosanitary Measures; FAO: Rome, Italy, 2007. 
41. International Plant Protection Convention (IPPC). ISPM 11-Pest risk analysis for quarantine pests, including analysis of environmental risks and living modified organisms. ISPM No. 11. In International Standards for Phytosanitary Measures; FAO: Rome, Italy, 2004.

42. International Plant Protection Convention (IPPC). ISPM 5. Glossary of phytosanitary terms. ISPM No. 5. In International Standards for Phytosanitary Measures; FAO: Rome, Italy, 2007.

43. EPPO Standards. Available online: https://www.eppo.int/STANDARDS/standards.htm (accessed on 18 June 2018).

44. EPPO-Computer Assisted Pest Risk Analysis-CAPRA. Available online: http://capra.eppo.org (accessed on 18 June 2018).

45. Gilioli, G.; Schrader, G.; Grégoire, J.C.; MacLeod, A.; Mosbach-Schulz, O.; Rafoss, T.; Rossi, V.; Urek, G.; Werf, W. The EFSA quantitative approach to pest risk-methodological aspects and case studies. EPPO Bull. 2017, 47, 213-219. [CrossRef]

46. Jeger, M.; Caffier, D.; Candresse, T.; Chatzivassiliou, E.; Dehnen-Schmutz, K.; Gilioli, G.; Grégoire, J.C.; Miret, J.; Anton, A.; MacLeod, A.; et al. Pest risk assessment of Atropellis spp. for the EU territory. FSA J. 2017, 15, 4877. [CrossRef]

47. Jeger, M.; Bragard, C.; Chatzivassiliou, E.; Dehnen-Schmutz, K.V.; Gilioli, G.; Anton, J.; Miret, J.; Macleod, A.; Navajas, M.; et al. Risk assessment and reduction options for Cryphonectria parasitica in the EU. EFSA J. 2016, 14, 4641. [CrossRef]

48. International Standards for Phytosanitary Measures ISPM 9. Generic elements for contingency plans. EPPO Bull. 2009, 39, 471-474. [CrossRef]

49. EPPO Global Database. Commodity-specific Phytosanitary Measures PM8. Available online: https://gd. eppo.int/standards/PM8/ (accessed on 18 June 2018).

50. EPPO Global Database. Available online: https://gd.eppo.int/ (accessed on 18 June 2018).

51. EFSA. Available online: https:/ / www.efsa.europa.eu (accessed on 18 June 2018).

52. Klapwijk, M.J.; Bylund, H.; Schroeder, M.; Björkman, C. Forest management and natural biocontrol of insect pests. Forestry 2016, 89, 253-262. [CrossRef]

53. EPPO Quarantine Pest. Data Sheets on Quarantine Pests: Anoplophora malasiaca and Anoplophora chinensis. 2018. Available online: https:/ /gd.eppo.int/taxon/ANOLCN/documents (accessed on 18 June 2018).

54. EPPO Quarantine Pest. Data Sheets on Quarantine Pests: Data Sheet on Anoplophora glabripennis. 2018. Available online: https:/ /gd.eppo.int/taxon/ANOLGL/documents (accessed on 18 June 2018).

55. EPPO Quarantine Pest. Data Sheets on Quarantine Pests: Data Sheet on Bursaphelenchus xylophilus. 2018. Available online: https:/ / gd.eppo.int/taxon/BURSXY/documents (accessed on 18 June 2018).

56. Figueiredo, J.; Simoes, M.J.; Gomes, P.; Barroso, C.; Pinho, D.; Conceicao, L.; Fonseca, L.; Abrantes, I.; Pinheiro, M.; Egas, C.; et al. Assessment of the geographic origins of pinewood nematode isolates via single nucleotide polymorphism in effector genes. PLoS ONE 2013, 8, e83542. [CrossRef] [PubMed]

57. EPPO. Mini Data Sheet on Phytophthora ramorum. 2013. Available online: https://gd.eppo.int/taxon/ PHYTRA/documents (accessed on 18 June 2018).

58. Brasier, C.; Webber, J. Sudden larch death. Nature 2010, 466, 824-825. [CrossRef] [PubMed]

59. Parke, J.L.; Rizzo, D.M. Phytophthora ramorum. For. Phytophthoras 2011, 1, 1. [CrossRef]

60. Wingfield, M.J.; Hammerbacher, A.; Ganley, R.J.; Steenkamp, E.T.; Gordon, T.R.; Wingfield, B.D.; Coutinho, T.A. Pitch canker caused by Fusarium circinatum-A growing threat to pine plantations and forests worldwide. Australas. Plant Pathol. 2008, 37, 319-334. [CrossRef]

61. Gordon, T.R.; Okamoto, D.; Storer, A.J.; Wood, D.L. Susceptibility of five landscape pines to pitch canker disease, caused by Fusarium subglutinans f. sp. pini. Hortscience 1998, 33, 868-871. [CrossRef]

62. Gordon, T.R.; Wikler, K.R.; Clark, L.; Okamoto, D.; Storer, A.J.; Bonello, P. Resistance to pitch canker disease, caused by Fusarium subglutinans f. sp. pini, in Monterey pine (Pinus radiata). Plant Pathol. 1998, 47, 706-711. [CrossRef]

63. Viljoen, A.; Wingfield, M.J.; Marasas, W.F.O. First report of Fusarium subglutinans f. sp. pini on pine seedlings in South Africa. Plant Dis. 1994, 78, 309-312. [CrossRef]

64. Pérez-Sierra, A.; Landeras, E.; León, M.; Berbegal, M.; García-Jiménez, J.; Armengol, J. Characterization of Fusarium circinatum from Pinus spp. in northern Spain. Mycol. Res. 2007, 111, 832-839. [CrossRef] [PubMed]

65. Iturritxa, E.; Mesanza, N.; Elvira-Recuenco, M.; Serrano, Y.; Quintana, E.; Raposo, R. Evaluation of genetic resistance in Pinus to pitch canker in Spain. Australas. Plant Pathol. 2012, 41, 601-607. [CrossRef] 
66. Bragança, H.; Diogo, E.V.; Moniz, F.V.; Amaro, P. First report of pitch canker on pines caused by Fusarium circinatum in Portugal. Plant Dis. 2009, 93, 1079. [CrossRef]

67. Carlucci, A.; Colatruglio, L.; Frisullo, S. First report of Pitch Canker caused by Fusarium circinatum on Pinus halepensis and P. pinea in Apulia (southern Italy). Plant Dis. 2007, 91, 1683. [CrossRef]

68. Chapin, E.; Chauvel, G. Phytosanitary overview for 2006 of tree plantations, shrubs and clumps in green spaces. In PHM Revue Horticole; P.H.M. Revue Horticole: Paris, France, 2007; Volume 490, pp. 40-44.

69. Landeras, E.; García, P.; Fernández, Y.; Braña, M.; Fernández-Alonso, O.; Méndez-Lodos, S.; Pérez-Sierra, A.; León, M.; Abad-Campos, P.; Berbegal, M.; et al. Outbreak of pitch canker caused by Fusarium circinatum on Pinus spp. in Northern Spain. Plant Dis. 2005, 89, 1015. [CrossRef]

70. EPPO. Available online: https://gd.eppo.int/taxon/GIBBCI (accessed on 18 June 2018).

71. Ganley, R.J.; Watt, M.S.; Manning, L.; Iturritxa, E. A global climatic risk assessment of pitch canker disease. Can. J. For. Res. 2009, 39, 2246-2256. [CrossRef]

72. Dvořák, M.; Rotkova, G.; Botello, L. Detection of airborne inoculum of Hymenoscyphus fraxineus and H.albidus during seasonal fluctuations associated with absence of apothecia. Forests 2016, 7, 1. [CrossRef]

73. Dvorák, M.; Janoš, P.; Botella, L.; Rotková, G.; Zas, R. Spore Dispersal Patterns of Fusarium circinatum on an Infested Monterey Pine Forest in North-Western Spain. Forests 2017, 8, 432. [CrossRef]

74. Bezos, D.; Martínez-Alvarez, P.; Fernández, M.; Diez, J.J. Epidemiology and Management of Pine Pitch Canker Disease in Europe-A Review. Balt. For. 2017, 23, 279-293.

75. Elvira-Recuenco, M.; Iturritxa, E.; Raposo, R. Impact of seed transmission on the infection and development of pitch canker disease in Pinus radiata. Forests 2015, 6, 9.

76. Serrano, Y.; Iturritxa, E.; Elvira-Recuenco, M.; Raposo, R. Survival of Fusarium circinatum in soil and Pinusradiata needle and branch segments. Plant Pathol. 2017, 66, 934-940. [CrossRef]

77. Forestry Commission. Contingency-plan-Pitch-canker-of-pine. DEFRA 2016. Available online: https:/ / www. forestry.gov.uk (accessed on 18 June 2018).

78. European Commission. Regulation (EU) No 1143/2014 of the European Parliament and of the Council 22 October 2014 on the Prevention and Management of the Introduction and Spread of Invasive Alien Species, Brussels, Belgium, 22 October 2014; Official Journal of the European Union, European Commission: Brussels, Belgium, 2014.

79. Roques, A.; Fan, J.T.; Courtial, B.; Zhang, Y.Z.; Yart, A.; Auger-Rozenberg, M.A.; Denux, O.; Kenis, M.; Barker, R.; Sun, J. Planting Sentinel European Trees in Eastern Asia as a Novel Method to Identify Potential Insect Pest Invaders. PLoS ONE 2015, 10, e0120864. [CrossRef] [PubMed]

80. Vettraino, A.; Roques, A.; Yart, A.; Fan, J.T.; Sun, J.H.; Vannini, A. Sentinel Trees as a Tool to Invasions of Alien Plant Pathogens. PLoS ONE 2015, 10, e0120571. [CrossRef] [PubMed]

81. Vettraino, A.M.; Li, H.M.; Eschen, R.; Morales-Rodriguez, C.; Vannini, A. The sentinel tree nursery as an early warning system for pathway risk assessment: Fungal pathogens associated with Chinese woody plants commonly shipped to Europe. PLoS ONE 2017, 12, e0188800. [CrossRef] [PubMed]

82. Eschen, R.; Rigaux, L.; Sukovata, L.; Vettraino, A.M.; Marzano, M.; Grégoire, J.C. Phytosanitary inspection of woody plants for planting at European Union entry points-A practical enquiry. Biol. Invasions 2015, 17, 2403-2413. [CrossRef]

(C) 2018 by the authors. Licensee MDPI, Basel, Switzerland. This article is an open access article distributed under the terms and conditions of the Creative Commons Attribution (CC BY) license (http://creativecommons.org/licenses/by/4.0/). 